\title{
Securitizing Sustainable Development? The Coercive Sting in SDG 16
}

\author{
Liora Lazarus
}

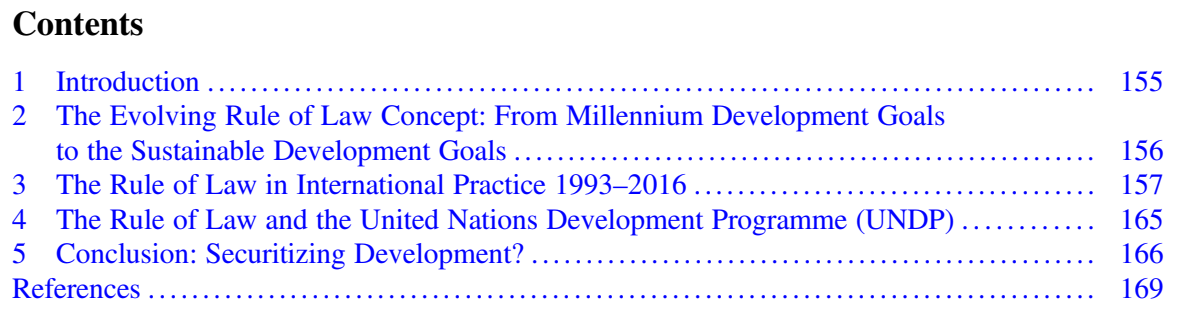

\begin{abstract}
SDG 16 includes the rule of law alongside a range of factors relating to violence and crime. In this respect, SDG 16 is reflective of a broader shift towards the securitization of the rule of law and human rights. Securitization here refers to the development of concepts to enhance the coercive function of the State. The chapter will demonstrate how SDG 16 thus sits in a broader context of the securitization of the rule of law in international practice, and raise concerns with this trend. The chapter concludes by warning about the potential further securitization of development generally.
\end{abstract}

\section{Introduction}

This chapter will argue that SDG 16 represents a culmination, or an exemplar, of a consistent paradigmatic shift—one we can describe as the securitization of the rule of law and human rights. It forms part of a broader academic project concerned with the question of how human rights and the rule of law may be used as legitimating

\footnotetext{
L. Lazarus $(\bowtie)$

Bonavero Institute of Human Rights, Law Faculty, University of Oxford, Oxford, UK

e-mail: liora.lazarus@st-annes.ox.ac.uk 
frameworks for coercive overreach of States. Securitization in this context thus implies the paradigmatic shift from the rule of law and human rights as concepts embodying the limitation of the coercive state, to ones integral to the maintenance of law order and security. This is a subtle process and one to which we need to pay more attention in the development process. In this pursuit an exploration of the rule of law's inclusion of Sustainable Development Goal 16, which also incorporates a range of factors relating to violence and crime, is instructive.

\section{The Evolving Rule of Law Concept: From Millennium Development Goals to the Sustainable Development Goals}

The concept of the rule of law travelled in the fifteen years between the Millennium Development Goals (MDGs) and the Sustainable Development Goals (SDGs), from a mechanism of international justice to one deeply embedded in the fight against failing states. In the MDGs, the rule of law featured in two respects. Under the goal of peace, security and disarmament, strengthening the international rule of law (particularly respect for ICJ decisions) was highlighted as a mechanism for avoiding the 'scourge of war', a concept implicitly understood there as international armed conflict. ${ }^{1}$ Under the goal of 'human rights, democracy and good governance' the rule of law was seen also as part of the project of strengthening human rights. ${ }^{2}$

The SDGs have a slightly different view of how 'freedom from violence' is to be realised. Instead of minimising international conflict by strengthening the international rule of law, the SDGs have positioned the rule of law as a tool to achieve the 'supremely ambitious and transformational vision' of 'a world free of fear and violence, ${ }^{3}$ a 'world ... in which every child grows up free from violence and exploitation' ${ }^{4}$ and in which 'all forms of discrimination and violence against women and girls will be eliminated'. The Rule of Law is thus there 'to foster just and inclusive societies which are free from fear and violence'. ${ }^{6}$ This goal is enunciated in SDG 16 which aims to "promote peaceful and inclusive societies for sustainable development, provide access to justice for all and build effective, accountable and inclusive institutions at all levels'.

One of the key detailed goals under this broader ambition is to 'promote the rule of law at the national and international levels and ensure equal access to justice for all' (16.3). The Rule of law goal is accompanied under SDG 16 by a number of indicators related to violence and crime as:

\footnotetext{
${ }^{1} \mathrm{~A} / \mathrm{RES} / 55 / 2$, para 9 .

${ }^{2} \mathrm{~A} / \mathrm{RES} / 55 / 2$, para 24 .

${ }^{3} \mathrm{~A} / 70 / 1$, para 7 .

${ }^{4} \mathrm{~A} / 70 / 1$, para 8 .

${ }^{5} \mathrm{~A} / \mathrm{RES} / 70 / 1$, para 20.

${ }^{6} \mathrm{~A} / \mathrm{RES} / 70 / 1,2 / 35$.
} 
inter alia, the goals to 'significantly reduce all forms of violence and related deaths everywhere' (16(1)), to 'end abuse, exploitation, trafficking and all forms of violence against torture of children' (16.2), 'significantly reduce illicit financial and arms flows, strengthen the recovery and return of stolen assets and combat all forms of organised crime (16.4), 'substantially reduce corruption and bribery in all their forms' (16.5), and 'strengthen relevant national institutions, including through international cooperation, for building capacity at all levels, in particular in developing countries, to prevent violence and combat terrorism and crime' (16a). SDG 16 thus undertakes to strengthen the rule of law 'at an international and national level' as a mechanism of 'promoting peaceful and inclusive societies'.

It has introduced the rule of law as a means to reduce violence, terrorism, corruption, trafficking, and serious crime in general at the domestic and transnational level, instead of the focus of the MDGs on avoiding 'international armed conflict'.

A short overview of usage of the rule of law in the United Nations General Assembly (UNGA) indicates that that the approach to the rule of law in the SDG's and SDG 16 in particular, as a mechanism of violence mitigation, as a strategy of shoring up fragile states, is right at the centre of a global emerging consensus. A consensus that views security as a precondition to many things: the good life, human rights, the rule of law, and development. The question is whether all of these concepts can remain intact when premised on this condition. The remaining chapter shows how the rule of law itself has been rearticulated as a mechanism of stability and security over the last decades. This provides a context for the shift between the MDGs and SDG 16, and perhaps as a warning to us.

\section{The Rule of Law in International Practice 1993-2016}

\section{United Nations General Assembly (UNGA)}

The Rule of Law really came prominently onto the international stage at the United Nations World Summit on Human Rights in Vienna in $1993,{ }^{7}$ when the rule of law was highlighted as a key aspect of human rights protection. Ever since this time, the rule of law has operated as a 'strategic and policy envelope' for the United Nations. ${ }^{8}$

In the beginning the emphasis of the Vienna Declaration was mostly on the 'rule of law' as an 'essential factor in the protection of human rights'. ${ }^{9}$ Nevertheless, the UNGA 'expressed its conviction that such a programme . . provide ... technical and financial assistance to national projects in reforming penal and correctional establishments, education and training of lawyers, judges and security forces in human rights, and any other sphere of activity relevant to the good functioning of the rule of

\footnotetext{
${ }^{7}$ United Nations, World Conference on Human Rights, 25 June 1993.

${ }^{8}$ Interview with UN official 1, 14 May 2014.

${ }^{9}$ Strengthening the rule of law, A/RES.48/132, 18 February 1994.
} 
law'. ${ }^{10}$ Already at this early stage, the institutional scope of rule of law activities included security and criminal justice components.

A line of annual resolutions entitled Strengthening of the Rule of Law followed. These sought to make concrete the lofty ambitions of the Vienna Declaration, though continued to highlight the dearth of funds available to do so. ${ }^{11} \mathrm{Key}$ also was the ongoing recognition that 'rule of law assistance' requests from member States were on the rise. ${ }^{12}$

Alongside, these attempts to embed the mission of the Vienna Declaration, a complementary approach to the Rule of law was developing within the UN. First, the United Nations Millennium Declaration incorporated the rule of law as we have already discussed.

Secondly, and more importantly, in August 2000, the Panel on United Nations Peace Operations reported to the UNGA and the United Nations Security Council (UNSC) on its 'comprehensive review of the whole question of peacekeeping operations in all their aspects'. ${ }^{13}$ This report, often referred to under the name of the panel Chairman, Lakhdar Brahimi, contained a range of rule of law proposals. Importantly, one of the key recommendations on peace building was a recommendation for a 'doctrinal shift in the use of civilian police and related rule of law elements in peace operations that emphasises a team approach to upholding the rule of law and respect for human rights and helping communities coming out of conflict to achieve national reconciliation'. ${ }^{14}$

Instead of providing a conceptual definition of the rule of law, the Brahimi report elaborated the notion of 'strengthening the rule of law' by example, in particular 'through training and restructuring of local police, and judicial and penal reform'. ${ }^{15}$ When taken together, Brahimi's bricolage of rule of law examples, began to give shape to a more security-centric conception of the rule of law, and significant institutional reform to achieve it.

The Brahimi approach has been hugely influential since its publication. This became clear in 2004 in the SG's report to the Security Council, The rule of law and transitional justice in conflict and post-conflict societies. ${ }^{16}$ This report enunciated a clear concept of the rule of law for the first time:

The 'rule of law' is a concept at the very heart of the Organization's mission. It refers to a principle of governance in which all persons, institutions and entities, public and private, including the State itself, are accountable to laws that are publicly promulgated, equally

\footnotetext{
${ }^{10} \mathrm{~A} / \mathrm{RES} .48 / 132$, para 2.

${ }^{11} \mathrm{~A} / \mathrm{RES} / 49 / 194 ; \mathrm{A} / \mathrm{RES} / 50 / 179 ; \mathrm{A} / \mathrm{RES} / 51 / 96 ; \mathrm{A} / \mathrm{RES} / 52 / 125 ; \mathrm{A} / \mathrm{RES} / 53 / 142 ; \mathrm{A} / \mathrm{RES} / 55 / 99 ;$ $\mathrm{A} / \mathrm{RES} / 55 / 221$.

${ }^{12} \mathrm{~A} / \mathrm{RES} / 57 / 221$ para 3.

${ }^{13} \mathrm{~A} / 55 / 305-\mathrm{S} / 2000 / 809$.

${ }^{14} \mathrm{~A} / 55 / 305-\mathrm{S} / 2000 / 809$, page 8, para 47 (b).

${ }^{15} \mathrm{~A} / 55 / 305-\mathrm{S} / 2000 / 809$, para 13.

${ }^{16}$ UNSC Report of the UN Secretary-General (23 August 2005). The rule of law and transitional justice in conflict and post conflict societies, S/2004/616*.
} 
enforced and independently adjudicated, and which are consistent with international human rights norms and standards. It requires, as well, measures to ensure adherence to the principles of supremacy of law, equality before the law, accountability to the law, fairness in the application of the law, separation of powers, participation in decision-making, legal certainty, avoidance of arbitrariness and procedural and legal transparency. ${ }^{17}$

This conception has been consistently applied since then. The most recent SG analytical summary of rule of law debates in the General Assembly between 2006 and 2015, described the definition as an 'important milestone in the area', pointing out 'numerous delegations expressed their agreement' with this definition in more recent years. ${ }^{18}$

Certainly, the SG definition includes classical state limiting norms normally espoused within the liberal rule of law canon. Nevertheless, it goes on to include private actors and institutions as subjects of the rule of law. This opens the door to the coercion of private actors and institutions as a necessary part of the rule of law, and engages by definition the criminal justice system as a whole.

It is also important to bookmark here that UN's rule of law definition was first presented within a report, and a forum, which was focused on security concerns. In the context of the UN General Assembly, this security-centric tone echoed sonorously in the 2005 report, In Larger Freedom. ${ }^{19}$ The report saw larger freedom, development and security, as going 'hand in hand', ${ }^{20}$ and emphasised the 'mutually reinforcing' ... 'right to security and to development'. ${ }^{21}$ Crucial to these twin aims and the achievement of 'collective security' is the shoring up of fragile states. Given the centrality of State capacity to collective security, the rule of law featured heavily in the report. Firstly, the rule of law featured as part of the 'freedom from want' agenda, by bolstering secure investment in developing economies. ${ }^{22}$ Secondly, it featured as a central tool of 'peace-building' and the attainment of 'freedom from fear'. ${ }^{23}$ Finally, a whole section was devoted to the rule of law in relation to 'freedom to live in dignity'.

But despite this title, the discussion of the rule of law mostly emphasised security and protection. Indeed, the report declared that the Millennium Declaration's emphasis was on the 'rule of law as the all-important framework for advancing human security and prosperity'. ${ }^{24}$ Strikingly, private actors threatening security, such as armed groups or terrorists were cast as those who 'make no pretence of being bound

\footnotetext{
${ }^{17}$ S/2004/616*, 23 August 2004, para 6.

${ }^{18}$ Strengthening and coordinating United Nations rule of law activities, A/70/206, 27 July 2015, Annex, para 8.

${ }^{19}$ In larger freedom: towards security, development and Human Rights for all, 21 March 2005, $\mathrm{A} / 59 / 2005$.

${ }^{20} \mathrm{~A} / 59 / 2005 /$ para 15 .

${ }^{21} \mathrm{~A} / 59 / 2005$, para 16.

${ }^{22} \mathrm{~A} / 59 / 2005$, para 36 .

${ }^{23} \mathrm{~A} / 59 / 2005$, para 115.

${ }^{24} \mathrm{~A} / 59 / 2005$, para 133.
} 
by the rule of law'. The phrase sought to describe a juxtaposition between a society following the rule of law and the threat of mass violence.

The Larger Freedom report was saturated with images of state collapse, and the violence that flows from a disregard for the rule of law and law in general. Strengthening the rule of law was seen as an answer not to the overreach of State coercion, but rather to the civic violence that erupts inside fragile States, or as a response to the impunity of those individuals responsible for breaches of international criminal law.

Following on from the 2005 World Summit Outcome document, the 'rule of law at the national and international levels' became a permanent annual agenda item on the Sixth Committee of the General Assembly. ${ }^{25}$ From this point, SG reports $^{26}$ and UN General Assembly resolutions ${ }^{27}$ on strengthening the rule of law were an annual feature.

Alongside this annual cycle, the concept of the rule of law has constituted a focus of other themed reports. In 2007, the rule of law as a foundation of security featured heavily in the SG's 'Comprehensive report on strengthening the capacity of the United Nations to manage and sustain peace operations ${ }^{, 28}$ This proposed a series of structural changes to the United Nations Department of Peacekeeping Operations (DPKO). The structural proposal was to divide the DPKO into five components, one of which would be the 'Office of Rule of Law and Security Institutions' (OROLSI). ${ }^{29}$

The 2007 report noted that 'one of the key aspect of the Brahimi report was its stress on the significance of the rule of law and public order for sustainable peace and security in countries emerging from conflict. ${ }^{30}$ But it also brought to that message the benefit of 7 more years of peacekeeping experience:

the lessons of the past decade of peacekeeping have also shown that the establishment and reform of the rule of law in post-conflict contexts is dependent on a basic level of security ... establishment of national security strategies and institutions operating under the rule of law are essential for the development of judicial, legal, correctional and police reform. This recognition has led to the initiation of comprehensive inter-agency consideration of the role of the United Nations in security sector reform. This exercise, while still ongoing, has underscored the linkage between the rule of law and security institutions.

\footnotetext{
${ }^{25}$ Organisation of the sixty-first session of the General Assembly, adoption of the agenda and allocation of items, First Report of the General Committee, A/61/250, paras 56, 75, 79.

${ }^{26}$ Reports of the Secretary General: the rule of law at the national and international levels, $\mathrm{A} / 62 / 121$, 11 July 2007; Strengthening and coordinating United Nations rule of law activities, A/63/226, 6 August 2008.

${ }^{27}$ General Assembly resolutions on the rule of law at the national and international levels: A/RES/ 62/70, 8 January 2008; A/RES/63/128, 15 January 2009; A/RES/64/116, 15 January 2010; A/RES/ 65/32, 10 January 2011; A/RES/66/102, 13 January 2012; A/RES/67/97, 14 January 2013; A/RES/ 68/116, 18 December 2013; A/RES/69/123, 18 December 2014.

${ }^{28} \mathrm{~A} / 61 / 858,13$ April 2007.

${ }^{29} \mathrm{~A} / 61 / 858$, para 26.

${ }^{30} \mathrm{~A} / 61 / 858$, para 57.
} 
Hence in 2008, a 'vision of security based on the rule of law' became part of the Secretary General's report on security sector reform. ${ }^{31}$ The report reinforced the clearly emerging UN consensus that the rule of law and security were now intertwined, featuring the 'rule of law' as the 'only' framework in which sustainable rights regarding security could be achieved, while also placing security itself as the 'precondition' to human rights. ${ }^{32}$

SG reports and GA resolutions on strengthening the rule of law continued on an annual basis, until the 2012 Declaration of the High-Level Meeting of the General Assembly on the Rule of Law at the National and International Levels. This declaration was similarly imbued with a sense of urgency about threats to peace and security. While also emphasising the constraining normative frameworks applying in the development of rule of law capacity, the General Assembly emphasized 'the importance of the rule of law as one of the key elements of conflict prevention, peacekeeping, conflict resolution, peace building' stressing 'justice' and 'transitional justice mechanisms' as key to this end. ${ }^{33}$ Similarly, it stressed the 'importance of supporting national civilian capacity development and institution-building in the aftermath of conflict'. 34

The resolution also reinforced the rule of law's place on the UNDP agenda, by articulating the inescapable connection between rule of law work and a range of development goals, as well as the 'right to development':

\begin{abstract}
We are convinced that the rule of law and development are strongly interrelated and mutually reinforcing, that the advancement of the rule of law at the national and international levels is essential for sustained and inclusive economic growth, sustainable development, the eradication of poverty and hunger and the full realization of all human rights and fundamental freedoms, including the right to development, all of which in turn reinforce the rule of law, and for this reason we are convinced that this interrelationship should be considered in the post-2015 international development agenda. ${ }^{35}$
\end{abstract}

Since the High Level Declaration, the UNGA has continued to generate annual resolutions reiterating its commitment to developing the 'rule of law at the national and international levels', and ${ }^{36} \mathrm{SG}$ reports in response to them. ${ }^{37}$ All of these reports stress the relationship between peace, security, development and the rule of law. There are too many to mention, but as an example the 2015 Report of the Special

\footnotetext{
${ }^{31}$ Securing peace and development: the role of the United Nations in supporting security sector reform, A/62/659-S/2008/39, 23 January 2008, para 4.

${ }^{32}$ On the growing influence of the idea that security constitutes a precondition to human rights see: Lazarus (2015).

${ }^{33} \mathrm{~A} / \mathrm{RES} / 67 / 1$, para 18.

${ }^{34} \mathrm{~A} / \mathrm{RES} / 67 / 1$, para 19.

${ }^{35} \mathrm{~A} / \mathrm{RES} / 67 / 1$, para 7.

${ }^{36}$ A/RES/67/97, 14 January 2013; A/RES/68/116, 18 December 2013; A/RES/69/123, 18 December 2014; A/RES/70/118, 18 December 2015.

${ }^{37}$ A/69/181, 24 July 2014; A/70/206, 27 July 2015.
} 
Committee on Peacekeeping Operations is again indicative of this trend. ${ }^{38}$ The report devoted an entire section to the rule of law emphasising on numerous occasions the "critical importance of strengthening the rule of law in countries in conflict and emerging from conflict in order to help stabilize the situation, extend State authority, end impunity, tackle the underlying causes of conflict and build lasting peace'. ${ }^{39}$ Similarly, the report 'underline[d] the important role that peacekeeping operations ... can play in helping national authorities ... to support the initial strengthening of the host State's rule-of-law institutions' ${ }^{40}$ The support of peacekeeping missions for rule of law institutions was a key focus, in particular with respect to early interventions aimed at 'maintaining basic law and order and fighting impunity by strengthening national police, justice and corrections institutions to restore the rule of law'. ${ }^{41}$ The range of rule of law actors acknowledged in the report were considerable, and a clear indication of how far rule of law work had become mainstreamed into both organisational reform of the UN itself and the management and structure of peacekeeping missions on the ground. ${ }^{42}$

This survey of UN General Assembly and Secretary General documentation on the rule of law has been purposively selective. Its aim is to highlight the growing emphasis on the conceptual relationship between the rule of law, security, law and order, peacekeeping and development. Undoubtedly, the UN's commitment to human rights, access to justice, and to the normative structures constraining and holding State's accountable to law is clear, consistent in all its publications and embedded in the SG's 2004 definition of the rule of law.

Nevertheless, the reference to 'private' persons, 'institutions and entities' and the idea of 'supremacy of law' provides a conceptual starting point for a broader conception of the Rule of Law as an apparatus aimed at maximising security and law and order, minimising violence, and embedding peace. It is unarguable that there is a continuous stream throughout all these documents linking the rule of law to the extension of State authority and the control of crime in fragile states. There is in short, a coercive sting in the tail of the Rule of Law, and no less so in SDG 16.

\footnotetext{
${ }^{38}$ Report of the Special Committee on Peacekeeping Operations 2015 substantive session, 17 March 2015, A/69/19.

${ }^{39} \mathrm{~A} / 69 / 19$, para 170 .

${ }^{40} \mathrm{~A} / 69 / 19$, para 171.

${ }^{41} \mathrm{~A} / 69 / 19$, para 175 .

${ }^{42} \mathrm{~A} / 69 / 19$, paras $176-185$. See also further Sect. 4 below.
} 


\section{United Nations Security Council (UNSC): Rule of Law Vacuums}

Let us turn briefly to the Security Council itself, where Rule of Law activity is ubiquitous. Probably the quickest and most instructive way to understand all aspects of the SC's working conception of the rule of law, is to look at its opposite construction: a 'rule of law vacuum' a term commonly invoked in the SC and in peacekeeping:

In post-conflict settings, legislative frameworks often show the accumulated signs of neglect and political distortion, contain discriminatory elements and rarely reflect the requirements of international human rights and criminal law standards. Emergency laws and executive decrees are often the order of the day. Where adequate laws are on the books, they may be unknown to the general public and official actors may have neither the capacity nor the tools to implement them. National judicial, police and corrections systems have typically been stripped of the human, financial and material resources necessary for their proper functioning. They also often lack legitimacy, having been transformed by conflict and abuse into instruments of repression. Such situations are invariably marked by an abundance of arms, rampant gender and sexually based violence, the exploitation of children, the persecution of minorities and vulnerable groups, organized crime, smuggling, trafficking in human beings and other criminal activities. In such situations, organized criminal groups are often better resourced than local government and better armed than local law enforcement. Restoring the capacity and legitimacy of national institutions is a long-term undertaking. However, urgent action to restore human security, human rights and the rule of law cannot be deferred. Thus, United Nations peace operations are often called upon to help fill this rule of law vacuum. ${ }^{43}$

Inside this 'rule of law vacuum' we see not only a legal system which violates rule of law norms, but also a system of enforcement which is dysfunctional and illegitimate and unable to control the rampant crime, violence and disorder described as 'better resourced' than government actors. The task, then, of rule of law intervention is to restore both the 'capacity' and the 'legitimacy' of 'local law enforcement'. While legitimacy of local law enforcement actors features large in this description, equal attention is given to their capacity to enforce order.

The experience of UNSC oversight of transitional societies after large scale conflict and atrocities over the past decade has reinforced the view that there is a key relationship between peace, stability and the elimination of 'rule of law' vacuums. Consequently, the nexus between security and the rule of law has been consistently emphasised in SC Secretary General reports and letters, ${ }^{44}$

\footnotetext{
${ }^{43}$ UNSC Report of the UN Secretary-General', S/2004/616*, 23 August 2004, para 27.

${ }^{44}$ UNSC Reports of the UN Secretary General: S/2004/616*, 23 August 2004; S/2006/980, 14 December 2006; S/2008/39, 23 January 2008; S/2008/460, 15 July 2008; S/2009/277, 29 May 2009; S/2009/304, 11 June 2009; S/2009/465, 16 September 2009; S/2010/288, 30 June 2010; S/2011/527, 11 August 2011; S/2011/634, 12 October 2011; S/2012/645, 15 August 2012. Letter from the UN Secretary General to the President of the UN Security Council, S/2012/958, 19 December 2012.
} 
SC reports, ${ }^{45}$ and SC Presidential Statements, ${ }^{46}$ and also evidenced by the establishment of a Rule of Law Assistance Unit within the Security Council. ${ }^{47}$

In the recent 2014 Statement, the Security Council President reaffirmed the 'importance of the rule of law as one of the key elements of conflict prevention, peacekeeping, conflict resolution and peace building'. ${ }^{48}$ The Statement went on to note 'the important role that the police components of peacekeeping operations can play in strengthening the rule of law in conflict and post-conflict situations, by, inter alia, providing operational support to national police and other law enforcement agencies and supporting the reform, restructuring and rebuilding of such agencies, including through technical assistance, co-location, training and mentoring programmes'. 49 There is little question therefore, that the language of the first thematic rule of law report has since become ubiquitous in official SC documentation.

In sum, from a closer analysis of their own sources, there is considerable evidence to show that UNSC peace building strategies are interleaved with a securitised conception of the rule of law. What the UNSC terms, 'citizen security' or a 'victim centred approach to peacekeeping', is at the heart of its pursuit of social ordering structures inside unstable societies. The practical operational realities of shoring up such structures has been repeatedly emphasised by the UNSC which has 'faced the difficulties of conducting peace operations where there are no functioning criminal justice mechanisms at all ${ }^{50}$ and that 'lawlessness can seriously undermine the efforts of entire peace operations'. As a consequence, the strategies for filling 'rule of law vacuums' in the first instance particularly include the role, capacities and obligations of military and civilian police components'. ${ }^{2}$

All of these peace keeping strategies, and resources to shore up security and order, are incorporated into the UNSC's framing of the 'the rule of law'. But there is insufficient conceptual attention to the distinction between the rule of law as a tool of security, stability and peace, and the normative ideals of the UNSG's rule of law concept as a state limiting device. The background coercive conditions which are necessary for the preservation of social order, are described as part of rule of law practice and rhetoric over and over again. There isn't a clear, consistent and

\footnotetext{
${ }^{45}$ S/PV.4833, 24 September 2003; S/PV.5052, 6 October 2004; S/PV.5474, 22 June 2006; S/PV.6347, 29 June 2010; S/PV.6705, 19 January 2012; S/PV.6849, 17 October 2012; S/PV.6913, 30 January 2013.

${ }^{46}$ S/PRST/2003/15, 30 September 2003; S/PRST/2004/2, 26 January 2004; S/PRST/2004/32, 10 September 2004; S/PRST/2005/30, 12 July 2005; S/PRST/2006/28, 22 June 2006; S/PRST/ 2010/11, 29 June 2010; S/PRST/2012/1, 19 January 2012; S/PRST/2013/1, 15/01/2013; S/PRST/ 2013/4, 15/04/2013; S/PRST/2014/3, 12 February 2014; S/PRST/2014/4, 14 February 2014; S/PRST/2014/5, 21 February 2014.

${ }^{47}$ Statement by the President of the UNSC, S/PRST/2006/28, 22 June 2006.

${ }^{48}$ Statement by the President of the UNSC, S/PRST/2014/5, 21 February 2014, page 1.

${ }^{49}$ Statement by the President of the UNSC, S/PRST/2014/5, 21 February 2014, page 2.

${ }^{50}$ UNSC Report of the UN Secretary-General', S/2004/616*, 23 August 2004, para 28.

${ }^{51}$ UNSC Report of the UN Secretary-General', S/2004/616*, 23 August 2004, para 10.
} 
concerted effort to distinguish security capacity building as an institutional pre-condition to the realisation of traditional rule of law safeguards. While there is consistent reference to human rights safeguards, justice and other values safeguarded by the rule of law, there is less consistent and explicit acknowledgement of the deep epistemological conflict between the measures aimed at bolstering fragile states and securing citizens, and those aimed at ensuring that the state is limited by rule of law safeguards.

\section{The Rule of Law and the United Nations Development Programme (UNDP)}

Let us turn now to the role of the UNDP within the Rule of Law architecture of the UN.

The UN now has a huge range of institutions involved in the delivery of rule of law work. At present there are two main bodies which co-ordinate this work at headquarter level. The Rule of Law Coordination and Resource Group (RoLCRG), ${ }^{52}$ which is chaired by the Deputy Secretary General, has the overall leadership role for rule of law work. The RoLCRG is made up of nine members, including the UNDP and DPKO, which in turn are responsible for 20 organisations in the delivery of rule of law assistance. ${ }^{53}$

The second important institution steering the Rule of Law in the UN is the 'Global Focal Point for Police, Justice and Corrections Areas in the Rule of Law in Post-conflict and other Crisis Situations' (GFP) established in 2012. The GFP brings key institutions together who will oversee crisis conditions on the ground, in particular the DPKO, and the UNDP. ${ }^{54}$ The GFP says it is there to "support the crisis system in delivering police, justice and corrections assistance to peacekeeping and political mission settings and other crisis situations, and to assist the United Nations country teams and missions to develop and implement common rule of law strategies

\footnotetext{
${ }^{52} \mathrm{https} / / / \mathrm{www}$.un.org/ruleoflaw/what-is-the-rule-of-law/coordination-of-rule-of-law-activities/ (last accessed 7 August 2019).

${ }^{53}$ The RoLCRG is made up of nine members: the Department of Political Affairs, the Department of Peacekeeping Operations (DPKO), the office of the High Commissioner for Human Rights (OHCHR); the Office of Legal Affairs; the United Nations Development Programme; the United Nations Development Fund for Women, and the United Nations Office on Drugs and Crime. This Group co-ordinates the activities of $20 \mathrm{UN}$ institutions which include the rule of law in their mandates: DESA, DPA, DPKO, OCHA, OHCHR, OLA, OSRSG for Children and Armed Conflict, OSRSG on Sexual Violence in Conflict, PBSO, UNDEF, UNEP, UNESCO, UN-Habitat, UNHCR, UNICEF, UNODC, UNOPS, UN Women, World Bank. The RoLCRG is supported by the Rule of Law Assistance Unit.

${ }^{54}$ The GFP also includes the Department of Peacekeeping Operations, the United Nations Development Programme, the Office of the High Commissioner for Human Rights, the United Nations Office on Drugs and Crime, and UN Women. See further in general: https://www.un.org/ruleoflaw/ what-is-the-rule-of-law/coordination-of-rule-of-law-activities/.
} 
and programmes. ${ }^{55}$ It is clear from the focus and design of the GFP that rule of law operations in crisis conditions intermesh development, human rights and security activity.

It is clear that the UNDP is part of both major rule of law networks within the UN, both general and in crisis missions. In particular, the UNDP is now deeply integrated into a rule of law partnership with the DPKO inside both of these networks. Consequently, it is not surprising that a peacekeeping aspect to the rule of law has travelled across to the UNDP. The role of the UNDP was outlined by the SG in 2008:

The UNDP plays an active role in crisis and post-conflict situations and supports the implementation of capacity-development programmes tailored to put in place foundations for recovery and development. UNDP assistance entails both justice and security and is geared towards long-term development and sustainability. At the request of Governments, UNDP emphasises the protection of civilians, access to justice and the rule of law and democratic governance in recovery and peace building environments.

Importantly, we can see from this description, that the UNDP is involved in the delivery of both justice and security - with a particular emphasis on the protection of civilians and on access to justice and the rule of law.

At the outset it must be acknowledged that the UNDP brings a different tone to rule of law interests. It promotes a broader and softer approach to the Rule of Law than the DPKO. It joins up the 'rule of law', 'justice', 'security' and 'human rights' in its account of its own work. ${ }^{56}$ Thus SDG 16 makes ample reference to 'fundamental freedoms' (SDG 16.10), and a range of normative goals (e.g. SDG 16.7'ensure responsive, inclusive, participatory and representative decision making' and SDG 16 b: promote and enforce 'non-discriminatory' laws and policies for sustainable development'). Similarly, the UNDP guidance on RoL indicators distinguishes between the 'often overlapping' concepts of 'rule of law', 'justice' and 'security'. 57

\section{Conclusion: Securitizing Development?}

Nevertheless, the intermeshing of peacekeeping and development goals as joint rule of law objectives leads inevitably to an emphasis on objectives which further the urgent need to shore up 'State authority' in crisis conditions as well as rights regarding normative structures. This is why SDG 16 includes concrete objectives relating to the reduction of crime and violence:

\footnotetext{
${ }^{55}$ Fact Sheet: Global Focal Point for Police, Justice and Corrections UNDP and DPKO, December 2012. http://www.undp.org/content/dam/undp/library/crisis\%20prevention/2012_12_07_The_ Fact_Sheet_for_Global_Focal_Point_Dec_2012.pdf (last accessed 7 August 2019).

${ }^{56}$ See UNDP website "Our Work": http://www.undp.org/content/undp/en/home/ourwork/demo cratic-governance-and-peacebuilding/rule-of-law\%2D\%2Djustice-and-security.html.

${ }^{57}$ UNDP, Why, What and How to Measure, p. 3.
} 
'significantly reduc(ing) all violence and related death rates everywhere' (16.1), ending "abuse, exploitation, trafficking and all forms of violence against and torture of children" (16.2), significantly reducing "illicit financial and arms flows, strengthen recovery and return of stolen assets and combat all forms of organised crime" (16.4), and "substantially reduc (ing) corruption and bribery in all their forms"'.58

These concrete crime and violence reduction objectives indicate that building the rule of law to further development and peacekeeping, goes hand in hand with crime control.

This message is repeated in other UNDP institutional material. The UNDP's rule of law co-ordinating function is led by the 'Rule of Law, Justice and Security Unit', which co-ordinates with OROLSI within the GFP. Its promotional material reiterates the message that the rule of law is the basis for security, stability, peace and development. ${ }^{59}$ Its simple message on its promotional video echoes the SC's 'rule of law vacuums' approach: "when the rule of law breaks down, society crumbles'. ${ }^{60}$ The video goes on to feature stabilising objectives such as the reduction of armed violence, the support of SGBV victims, and the promotion of national reconciliation, as successes of joint rule of law efforts between the UNDP and DPKO working on the ground. ${ }^{61}$

Similarly, in the 2014 UNDP User's Guide to Measuring Rule of Law, Justice and Security Programmes, the UNDP makes it clear that 'strengthening the rule of law ... is critical in crisis affected countries as a key element of state and peace building', and is unequivocal about the umbilical link between securing the rule of law and development (echoing the High Level Declaration of the UNGA of 2012 ${ }^{62}$ ):

In September 2012, Member States in the General Assembly of the United Nations reaffirmed that the rule of law is critical for sustainable development. Indeed, the rule of law is an important factor in accelerating achievement of the MDGs and will be essential to the post-2015 Development Agenda as both an enabler and an outcome of development in its own right. It is now beyond question that improving safety for individuals and communities, and providing access to fair and well-functioning legal systems that adhere to international human rights standards, are necessary to promote economic investment, prevent violence and conflict, encourage inclusive growth and eradicate poverty. To these ends, governments, civil society groups and multilateral actors have in many cases increased the resources specifically devoted to the rule of law area. ${ }^{63}$

\footnotetext{
${ }^{58}$ Transforming our world: the 2030 Agenda for Sustainable Development, A/RES/70/1, 21 October 2015.

${ }^{59} \mathrm{http}: / /$ www.undp.org/content/undp/en/home/ourwork/democratic-governance-andpeacebuilding/rule-of-law\%2D\%2Djustice-and-security.html — see video on this page: UNDP and the Rule of Law (last accessed 10 August 2019).

${ }^{60} \mathrm{http}: / / \mathrm{www}$. undp.org/content/undp/en/home/ourwork/democratic-governance-andpeacebuilding/rule-of-law\%2D\%2Djustice-and-security.html — see video on this page: UNDP and the Rule of Law (last accessed 10 August 2019).

${ }^{61} \mathrm{http}: / / \mathrm{www}$. undp.org/content/undp/en/home/ourwork/democratic-governance-andpeacebuilding/rule-of-law\%2D\%2Djustice-and-security.html—see video on this page: UNDP and the Rule of Law (last accessed 10 August 2019).

${ }^{62} \mathrm{See} \mathrm{A} / \mathrm{RES} / 67 / 1$, para 7, 8, 24, 25, 30, 41. See section X above.

${ }^{63}$ UNDP (2014) Why, what and how to measure: a user's guide to measuring rule of law, justice and security programmes. http://www.undp.org/content/dam/undp/library/crisis\%20prevention/ UNDP_CPR_ROLMEGuide_August2014.pdf (last accessed on 10 August 2019).
} 
Likewise, in the UNDP's strategic plan for 2014 to 2017, Changing with the World, rights regarding and security enhancing objectives are both evident. The plan features the goal of 'reinforcing the rule of law and citizen security' as a 'critical aspect of well-being' ${ }^{64}$ It notes that progress towards this important strategic goal will include both 'security sector reform', measures to 'ensure respect for citizen rights' and 'stronger civilian oversight' as well as 'faster progress in reducing gender-based violence', 'policing for reduction of crime and anti-social behaviours and attitudes'. All of these are said to 'improve prospects for success on citizen security'. ${ }^{65}$ The UNDP's strategic goals are clearly now aligned with the ambitious violence reduction goals of the SDG's. No matter how well committed the UNDP may be to softer community enhancing and rights regarding forms of peacekeeping, the concrete goals of violence reduction also necessitate a commitment to shoring up the coercive structures of member States. This is simply unavoidable.

This shift in the securitization of the rule of law has not gone unnoticed. As Bergling, Wennerstrom, and Sannerholm argue: 'the character of international community responses to rule of law threats and challenges has a strong focus on security. Rule of law promotion taking place in UN and EU missions has undergone a 'securitisation' in how reforms are conceived and put into practice'. 66

Indeed, some view the shift as deeply corrosive of the concept of the rule of law. As Humphreys argues:

\footnotetext{
Where the rule of law comes to signify the coercive capacity of the state and its disciplinary structures and effects, rather than its constraints; when it signifies the rights of victim, rather than the accused; when it is measured in convictions and boots on the ground, rather than in the texture of the social fabric, something has surely been lost. When such an effect is promoted consistently, country-by-country at global level, through numerous channels, that loss begins to look irrevocable. ${ }^{67}$
}

We may well ask too whether this focus on peacekeeping is potentially just as corrosive of the notion of development which until now has clung to a softer community-based approach to security and rule of law intervention. But if this discrete approach to security is to be maintained, a greater honesty about the risk of securitization within the SDGs and SDG 16 needs to be sustained. What we see in SDG 16 is a goal of empowerment, but the licence it gives to the idea of crime control and the coercion of private violence isn't always about empowerment. It is also about social control.

\footnotetext{
${ }^{64}$ UNDP, Changing with the World, UNDP Strategic Plan: 2014-17, New York. Available at http:// www.undp.org/content/undp/en/home/librarypage/corporate/Changing_with_the_World_UNDP_ Strategic_Plan_2014_17.html (last accessed 17 August 2019).

${ }^{65}$ Changing with the World, pp. 30-31.

${ }^{66}$ Bergling et al. (2012), p. 99.

${ }^{67}$ Humphreys (2010), p. 174.
} 


\section{References}

Bergling P, Wennerstrom P, Sannerholm R (2012) Rule of law and security sector reform: casual assumptions, unintended risks and the need for norms. Hague J Rule Law 4:98-119

Humphreys S (2010) Theatre of the rule of law: transnational legal intervention in theory and practice. Cambridge University Press

Lazarus L (2015) The right to security. In: Cruft et al (eds) The philosophical foundations of human rights. Oxford University Press, Oxford, pp 423-441

Liora Lazarus BA (UCT), LLB (LSE), DPhil (Oxon), is an Associate Professor in Law, and a Fellow of St. Anne's College, University of Oxford. Her primary research interests are in comparative human rights, security and human rights, comparative theory and comparative criminal justice. Born and raised in South Africa, she studied African Economic History at the University of Cape Town and Law at the London School of Economics and Political Science. From 1994 to 1995 she was a Fellow of the Max Planck Institute for Foreign and International Criminal Law, Freiburg, Germany. She came to Oxford in 1995 to write her doctorate at Balliol College, after which she went on to become a law fellow at St Anne's College. Dr. Lazarus's various academic publications are in the area of prisoners' rights, criminal justice and security and human rights. She has completed public reports for the UK Ministry of Justice on balancing public protection with human rights, and on the relationship between rights and responsibilities. She has acted as an advisor to the UK Stern Review on Rape Complaints, was asked to give evidence to the Parliamentary Modern Slavery Bill Committee, and was part of an International Committee of Experts to the Basque Working Group on Treatment of Political Detainees. Dr. Lazarus co-founded and is actively involved in the work of Oxford Pro Bono Pulico. She is also an Associate of the Oxford Human Rights Hub. Dr. Lazarus is an Academic Affiliate of the Bonavero Institute of Human Rights at Oxford and a Member of Oxford's Centre for Criminological Research. She sits on the Advisory Board of the Max-Planck Encyclopedia of Comparative Constitutional Law. Dr. Lazarus founded and now acts as the series editor of the Hart Studies in Security and Justice.

Open Access This chapter is licensed under the terms of the Creative Commons Attribution 4.0 International License (http://creativecommons.org/licenses/by/4.0/), which permits use, sharing, adaptation, distribution and reproduction in any medium or format, as long as you give appropriate credit to the original author(s) and the source, provide a link to the Creative Commons licence and indicate if changes were made.

The images or other third party material in this chapter are included in the chapter's Creative Commons licence, unless indicated otherwise in a credit line to the material. If material is not included in the chapter's Creative Commons licence and your intended use is not permitted by statutory regulation or exceeds the permitted use, you will need to obtain permission directly from the copyright holder.

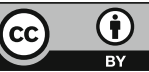

